\title{
AC 2008-1879: A PARTNERSHIP FOR PEACE: HOW COOPERATION BETWEEN THE NATIONAL MILITARY ACADEMY OF AFGHANISTAN AND KABUL UNIVERSITY BENEFITS BOTH INSTITUTIONS AND THE AFGHAN NATION
}

\author{
Richard Gash, United States Military Academy \\ Major Richard Gash, P.E. is an instructor in the Department of Civil and Mechanical Engineering \\ at the U.S. Military Academy (USMA), West Point. He graduated from USMA in 1996, with a \\ Bachelor of Science Degree in Civil Engineering. He has since earned Master of Science Degrees \\ in Geophysics from the University of Missouri, Rolla and Earthquake Engineering from the \\ University of California, Los Angeles. He has served in a variety of military assignments around \\ the world including Iraq and Afghanistan. During the summer of 2007 he served as a member of \\ the implementation team at the National Military Academy of Afghanistan.
}

\section{Christopher Conley, United States Military Academy}

Chris Conley is an Associate Professor in the Department of Civil and Mechanical Engineering at the U.S. Military Academy. He earned a B.S. degree in Civil Engineering from the University of Massachusetts (1978), and M.S. and Ph.D. degrees in Civil Engineering from Cornell University (1980, 1983). He has served as a Member of Technical Staff at Sandia National Laboratories, a Senior Research Associate at Cornell University, and an Assistant Professor at the University of Massachusetts Lowell. In his 13 years on the USMA faculty he has taught a variety of courses in the civil and mechanical engineering programs, and has collaborated on research with Army laboratory personnel.

\section{Scott Hamilton, United States Military Academy}

Lieutenant Colonel Scott Hamilton is currently the Senior Advisor and Team Chief at the National Military Academy of Afghanistan in Kabul, Afghanistan . He earned a B.S. degree from USMA, and Master of Science degrees in Civil Engineering and Engineering Management from Stanford University in 1994. An active duty Army officer, he has served in a variety of military engineering assignments around the world and is a registered professional Engineer in California. He has been an Assistant Professor in the Department of Civil and Mechanical Engineering at the U.S. Military Academy (USMA), West Point for 7.5 years, teaching courses in engineering mechanics, structural analysis and Home Brewing.

\section{Paul Krajeski, U.S. Naval War College}

Lieutenant Colonel Paul C. Krajeski is currently assigned to the Naval War College, Newport, Rhode Island as faculty in the Strategy \& Policy Department. He graduated with an Infantry commission from the United States Military Academy in 1985 and holds a Ph.D. in History from Florida State University. In his previous assignment, Lieutenatn Colonel Krajeski supported Operation ENDURING FREEDOM at the National Military Academy of Afghanistan in Kabul, where he was Chief of the American Implementation Team from 2006 - 2007. Other assignments include various Infantry positions in Korea, 1st Ranger Battalion, "The Old Guard," Ft.

Campbell, and Kosovo. Additionally, he was the Professor of Military Science for the University of Rhode Island ROTC from $2002-2006$.

\section{Stephen Ressler, United States Military Academy}

Colonel Stephen Ressler is Professor and Head of the Department of Civil and Mechanical Engineering at the U.S. Military Academy (USMA), West Point. He earned a B.S. degree from USMA in 1979, a Master of Science in Civil Engineering degree from Lehigh University in 1989, and a Ph.D. from Lehigh in 1991. An active duty Army officer, he has served in a variety of military engineering assignments around the world. He has been a member of the USMA faculty for 16 years, teaching courses in engineering mechanics, structural engineering, construction, and professional practice. 


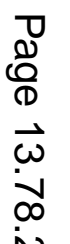

iు 


\title{
A Partnership for Peace: How cooperation between the National Military Academy of Afghanistan and Kabul University benefits both institutions and the Afghan Nation
}

\begin{abstract}
In the winter of 2007 the leadership of the National Military of Afghanistan (NMAA) and the Dean of Engineering at Kabul University formed a partnership designed to meet the immediate needs of both institutions. After just a few short months the intended results of the partnership are already being realized. More importantly however, a greater strategic benefit soon began to emerge. Upon graduation, the cadets from NMAA will provide the Afghan National Army with a new generation of leaders--professionals who have been educated, in part, by members of Kabul University, one of the most respected academic institutions in the region. Should their spirit of cooperation extend the beyond the classroom it will help legitimize the Afghan Government, thus contributing to national and regional stability.
\end{abstract}

The partnership was devised and implemented by advisors to the Afghan Academy from the United States Military Academy (USMA). Under the agreement Kabul University provides the Afghan Academy with adjunct instructors for its fledgling engineering program. In return, the University benefits through its faculty working closely with the USMA advisors and having access to the most up-to-date US engineering texts educational material that they otherwise would not have access to. Furthermore Kabul University, whose engineering laboratories have been wasted by years of conflict under both the Soviets and the Taliban, can also benefit from NMAA's state of the art lab facilities.

The partnership is working and even growing. The Academy recently completed its first term of engineering instruction and three of the Kabul University adjuncts have been selected for graduate fellowships in the United States. Kabul University has prepared a second set of instructors to facilitate NMAA's next academic semester. This early success has reinforced the partnership. Both institutions are fully committed to its continued success and looking for ways to expand it. Options to do so include joint field trips, lectures, and student conferences. The Academy is also considering establishing a similar relationship with the Polytechnic University of Kabul.

Afghanistan today is in desperate need of engineers to help rebuild its national infrastructure. The National Military Academy of Afghanistan, with the help of Kabul University, is poised to provide military engineers ready for the task.

\section{Introduction}

In the early months of 2007 the leadership of the National Military Academy of Afghanistan (NMAA) and the Dean of Engineering at Kabul University formed a partnership designed to meet the immediate needs of both institutions. For NMAA that need was clear: identify qualified instructors to teach the civil engineers desperately needed by the nascent Afghan National Army (ANA). Kabul University's need was more abstract: further develop 
their promising young academic talent and find a way to keep them from being lured into an extremely lucrative and rapidly expanding private engineering sector. After less than a year, these intended results are being realized. The partnership is healthy and even expanding. More importantly however, a greater strategic benefit is becoming apparent. Upon graduation the cadets of NMAA will form a new generation of leaders for Afghanistan-professionals who have been, at least in part, educated by the faculty of Kabul University. Their spirit of cooperation has laid a foundation for future collaboration. Should this extend beyond the classroom, it has the potential to help integrate the ANA into Afghan society at large, thus serving to legitimize the Afghan government and directly contributing to national stability.

\section{A Military Academy to Provide Engineers for a Nation}

For the government of Afghanistan to succeed it must be able to protect its people, provide basic services, and enforce the rule of law. A large part of this burden lies with the ANA. Trained and equipped by the coalition deployed under the leadership of the United States Central Command's Combined Security Transition Command - Afghanistan (CSTC-A) and working with partner nations largely from the North Atlantic Treaty Organization (NATO), the ANA currently numbers fifty-seven thousand soldiers and is growing daily. In an effort to provide a corps of professional officers to this growing force, in 2005 the Afghan government established a military academy envisioned to become "the crown jewel of university level educational and leader development institutions in Afghanistan" to produce graduates that "will set the highest standards of professionalism throughout a lifetime of service to Afghanistan."1

Two hundred years ago the founders of another nation, one also ravaged by war and struggling to create a national government and identity, identified the need for a national military academy. Alexander Hamilton, John Adams, and Thomas Jefferson were among those who set the conditions for the United States Congress in 1802 to authorize a military academy at West Point, New York ${ }^{2}$. The United States Military Academy would go on to become the first school of engineering in the English-speaking world. West Point graduates would prove critical to American growth and expansion. They surveyed and settled the western territories, brought railroads over the Rocky Mountains, and built the Panama Canal ${ }^{3}$. They led the soldiers that have fought and won our nation's wars. They have served at the highest levels of our Government. Like NMAA, West Point also had help during its formative years. As there were no other engineering institutions in United States at the time, West Point's early support came primarily from the École Polytechnique of France. Today, more than two hundred years later, West Point continues to produce engineer leaders and remains among the United States' leaders in engineering education ${ }^{4}$.

The National Military Academy of Afghanistan owes much to West Point. Since 2003 CSTC-A has maintained an implementation and support team dedicated to assisting NMAA. The team consists of military administrators and educators who advise the Academy's faculty and staff. The United States Military Academy, in conjunction with the United States Air Force Academy and the Turkish Army, has provided many of these mentors. West Point's influence can be found throughout NMAA's four year curriculum. Similar to West Point's broad based curriculum, the Afghan cadets study a broad based curriculum in the tradition of liberal arts education that includes engineering. Although the Afghan cadets can currently choose from five 
majors (civil engineering, computer science, law, English language, and leadership) all must take a core civil engineering curriculum.

\section{The Need for Cooperation}

Autumn of 2006 found NMAA seeking to recruit instructors qualified to teach those engineering classes. During the coming spring the initial class of cadets, set to enter their third year of instruction, would begin the specialized courses that would contribute to their major fields of study and the core engineering curriculum. The leadership of the Afghan Academy quickly encountered a serious problem--the Afghan National Army did not have officers trained or educated in engineering. Expanding the search to the civilian population proved no better. None of the few qualified engineers remaining in the country could be enticed away from the private sector. The construction boom resultant from massive infusions of capital from the coalition, foreign investors, and non-governmental organizations put their skills in high demand. To complicate matters, The Afghan Ministry of Defense salaries were simply not competitive. (At the time, the typical salary for an Afghan National Army officer serving at NMAA was three hundred U.S. Dollars per month. An engineer working in the private sector could easily make three to four times that amount.) Faced with no other options, the NMAA leadership and the U.S. Mentor team turned to the existing academic institutions for help. On October 3, 2006 the U.S. Mentor team chief and the Dean of the NMAA traveled to Kabul University on a mission to hire adjunct faculty.

Kabul University was founded in 1932. It quickly gained respect within the region as a center for quality education and progressive thinking. By the late 1960s, the University consisted of colleges of Medicine, Law, Engineering, Pharmacy, and Agriculture, among others. It attracted many western educated scholars and served as a true center of new ideas and thought ${ }^{5}$. Tragically, the ensuing thirty years of war took a huge toll on the University. It suffered immensely during the Soviet occupation of the 1980s and civil war of the early 1990s. As contact with the outside world diminished leading scholars fled and scientific research stagnated. During the Taliban's ascendancy in the middle 1990s, the University was eviscerated. Once proud facilities were bombed, looted, and left without utilities ${ }^{6}$. Despite this, both teaching and learning never completely stopped. A dedicated core of professors and students kept the University alive. They attended class under deplorable conditions, often at great risk to their lives ${ }^{7}$. Fortunately the university is currently undergoing a dramatic revitalization. Foreign aid has begun to restore long neglected facilities. Partnerships with institutions such as Purdue University and Kansas State University have improved pedagogy and introduced technology to the classrooms. To accommodate their own rapidly expanding enrollments, the Faculty of Engineering had begun a policy of offering teaching positions to the top graduates from each class. Although these appointments offered much in the way of prestige the University was able to offer little in the way of salary. With the lure of the private sector always looming, the Faculty of Engineering was having trouble keeping their new hires. Some of these young engineers would form the core of the partnership between the two institutions.

They were, in fact, the main topic of conversation between the party from NMAA and Dr. Ata M. Nazar, Kabul University's Dean of Engineering, on that first visit. Although it took several more visits to demonstrate good faith and build trust, NMAA and the U.S. mentor team 
eventually secured an agreement from Dr. Nazar to provide Kabul University instructors to the Academy to serve as adjunct faculty. Three recent graduates and one more experienced assistant professor would teach six sections of Introduction to Statics and Engineering Design and one section of Introduction to Civil Engineering. Thus was formed the National Military Academy of Afghanistan's Department of Civil Engineering. At the time none of the parties involved could have foreseen the additional benefits of the partnership.

\section{Both Sides Benefit}

The National Military Academy of Afghanistan realized the benefits first when, on the $24^{\text {th }}$ of March, 2007 the junior class of cadets began their first engineering studies. Ironically, thanks to the ponderous Afghan Ministry of Defense logistics system, they had no desks! Instead they had energetic, motivated instructors prepared to teach them the basics of Civil Engineering. Without the help of the Faculty of Engineering at Kabul University this would not have been possible. Beyond lesson plans and lectures the adjuncts brought to NMAA both professional and academic credibility. Three adjuncts had recently graduated at the top of their respective classes from Kabul University. The fourth was a seasoned educator with years of experience. These credentials ranked them among the elite of Afghanistan's scholars and educators making them much more qualified to teach at the college level than most of NMAA's military faculty. Their connections to Kabul University increased the Academy's standing with both the Afghan Ministry of Higher Education and the Ministry of Defense. Perhaps most telling of how highly the Academy valued their adjunct engineering faculty was where they ate lunch. At the start of their tenure, the adjuncts were reluctant to eat at the Academy's mess hall with the military faculty. After six months, they regularly dined at the head table with the Academy's Commanding General, an honor typically reserved for the Academy's senior leadership.

The benefits realized by Kabul University, however, certainly extend far beyond a few good meals. As the first semester progressed, it became clear that the faculty involved and the University as a whole would profit much more than expected by the arrangement. Daily contact with the mentor team allowed the adjuncts to absorb, and bring back to their own institution, all the pedagogical assistance that was intended for NMAA. During the months leading up to the start of the Academy's engineering classes, the mentor team worked closely with the adjuncts to adapt West Point's curriculum to the conditions at the Academy in Afghanistan ${ }^{8}$. As the mentor team prepared the Afghans for the classroom, they shared many of the principles they use to prepare their own faculty. These included, in addition to lessons plans and current textbooks, the methods packaged by West Point for the American Society of Civil Engineers' Excellence in Civil Engineering Education (ExCEEd) teaching workshop. The mentor team also introduced the adjuncts to the use of technology in the classroom. Thanks to financial support from the U.S., the National Military Academy of Afghanistan proudly boasts a computer aided design lab complete with video projector and smart board. The mentor team worked with the Afghan adjuncts to ensure they understood the software needed to incorporate these tools into the curriculum 9 . As international aid allows Kabul University to invest in technology, the adjuncts abilities will greatly facilitate implementation. In addition to automation, the U.S. mentors also brought state-of-the-art laboratory equipment. When outfitting NMAA's civil engineering labs, they ensured they purchased the same equipment found in West Point's labs. This allowed the mentors to implement programs similar to those at West Point and would facilitate efforts to 
troubleshoot and correct future maintenance problems from afar after their redeployment. Again, the Afghan adjuncts benefitted from the use of all this equipment. In some instances they were able to borrow equipment for use in their Kabul University courses.

In the summer of 2007, near the end of the partnership's first semester, both institutions realized yet another unexpected benefit. Three of the Adjuncts received fellowships to pursue post-graduate study in the United States at Ohio University. Their ties to the National Military Academy of Afghanistan played a significant role in their selection. Their work at the Academy demonstrated a deep commitment to the future of Afghanistan. They will return well poised to improve the quality of engineering education at both the Academy and Kabul University. As the first cadre of adjuncts departed for Ohio, Kabul University's Dean of Engineering readily filled the vacancies with a new set of adjuncts. For the near future, adjunct requirements will continue increasing to meet the demands of NMAA's expanding enrollment. Kabul University has eagerly committed to fill these needs.

\section{Room for Growth}

As successful as it has been, there is yet room for the partnership to grow. In the 1960's, the Soviet Union sponsored establishment of Kabul Polytechnic Institute. Intended to help exploit the natural resources of Afghanistan, the Institute served as a post-secondary technical school that offered students degrees in Engineering. Staffed and supported by the Soviet Union, the Institute quickly gained academic notoriety. While Kabul University suffered under Soviet occupation, the Polytechnic Institute flourished ${ }^{10}$. Like Kabul University, it survived the Taliban but not without major damage to its facilities and resources. Today, thanks in part to efforts from several German Institutions including the University of Applied Sciences at Karlsruhe, it is under going a resurgence of its own. The Institute now offers programs of study in construction, geology and mining, and electro-mechanics ${ }^{11}$. During their search for engineering instructors, the NMAA implementation team visited Kabul Polytechnic Institute. Initial efforts to recruit their faculty to serve as adjuncts at the Academy did not succeed. Recently, however, the United States Army Corps of Engineer's Afghan Engineer District has had success hiring Kabul Polytechnic graduates to serve as project engineers. Perhaps the success of the Kabul University adjuncts at NMAA can entice the Institute to enlist in the partnership as well. The inclusion of this educational resource has the potential to propagate the spirit of cooperation to another sector of Afghanistan's intellectual elite.

\section{Hope for the Future}

Afghanistan today is a nation hungry for engineers. Soviet occupation, the struggle for power following their departure, and the Taliban's brutal rule took a heavy toll on the country's intellectual capital. Many engineers fled. Many were killed. The same unrest devastated the Nation's infrastructure. Now, as international aid begins to pour in, engineers are needed to rebuild-engineers committed to service to their nation. It is the Afghan government's goal that the National Military Academy of Afghanistan will help provide these engineers. Two hundred years ago, West Point provided many of the engineers who surveyed the land and built the roads, railways, waterways that facilitated our nation's expansion. It is up to the young engineers of Afghanistan to do the same for their nation. As the National Military Academy of Afghanistan's 
civil engineering cadets begin assuming leadership roles in the Afghan government and the Afghan National Army they will be equipped with a first class education. The Faculty of Civil Engineering at Kabul University will also continue producing engineers. Their graduates will enter both the private and public sectors. A robust atmosphere of respect and cooperation between the two academic institutions cannot help but influence their graduates. At this point in Afghan history, a united engineering community is essential. Military, governmental, private sector, and academic engineers must work together in order to develop and realize a vision for their nation's reconstruction. Every road that is built must be maintained, every sewage plant must be operated, and every power grid must be connected. Doing so will lead to a healthy national infrastructure-one that will give the Afghan people confidence in their government's ability to rule.

Cadets from the National Military Academy of Afghanistan's first class will graduate in January of 2009. When they do, eighteen new civil engineers will begin service to their nation. It remains to be seen if they will be the first wave of a tradition as successful as that of West Point or if the spirit of respect and cooperation now kindled between the Academy and Kabul University will endure. One thing, however, is certain: Every member of the Kabul University faculty that supports the National Military Academy of Afghanistan joins every cadet they taught in serving as building blocks in the foundation of their country's future.

1. National Military of Afghanistan Concept Plan, Written agreement between members of the Office of Military Cooperation-Afghanistan and the Afghan Ministry of Defense, (2003, Updated 2005)

2. Stephen E. Ambrose, Duty, Honor, County (Batimore: John Hopkins Press, 1966)

3. Sidney Forman, "The First School of Engineering," in Sons of Martha, ed. Augustine J. Fredrich (New York: American Society of Civil Engineers, 1989)

4. U.S. News \& World Report, “America's Best Colleges, 2008,” [http://colleges.usnews.rankingsandreviews.com], (17 January 2008)

5. Ludwig W. Adamec, Historical Dictionary of Afghanistan, $3^{\text {rd }}$ Edition, (Oxford: The Scarecrow Press, 2003), 203-205

6. Amy M. Rubin, “A Bleak Future for Afghan Higher Education," The Chronicle of Higher Education, (September 1997, Volume 44, Issue 2)

7. Llyod Marion, "Kabul U. Struggles Amid the Ruins," The Chronicle of Higher Education, (January 1999, Volume 45, Issue 19)

8. Stephen J. Ressler, et al, "Designing a Civil Engineering Program for the National Military Academy of Afghanistan." Submitted to the Proceedings of the 2008 ASEE Annual Conference, (Pittsburgh, June 2008)

9. Richard J.H. Gash, "Technology in the Classroom: When the Afghan's Get IT Right," CTE Today: A Newsletter for Teachers at USMA, (November 2007)

10. Ludwig W. Adamec, Historical Dictionary of Afghanistan, 308

11. Kabul Polytechnic Institute, [http://www.polytechnic-kabul.org], (16 January 2008) 